\title{
Lived experience of literature teachers and students in the new normal
}

\author{
Pordunzalan, Rio $₫$ \\ Laguna College of Business and Arts, Philippines (Rpordunzalan14@gmail.com)
}

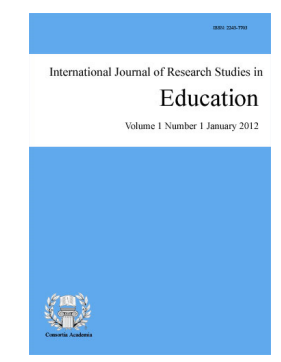

Accepted: 5 August 2021 Online ISSN: 2243-7711

OPEN ACCESS

\section{Abstract}

This study was conducted to explore the lived experience of literature teachers and students in the new normal, particularly in dealing with Online Distance learning modality. The participants of the study were the Grade 9 Literature teachers and Grade 9 students from selected Junior High Schools in the private schools of Batangas. The study utilized qualitative research with interpretative phenomenology analysis as the approach in order to explore in detail the participants personal experience and its meaning. A validated self-made interview questionnaire was used as the primary data gathering instrument. The data collected were transcribed and analyzed to formulate themes. The themes were as follows: Diverse Perspectives, Different Viewpoints, Various Preparations, Varied Adjustments, Distinct Challenges, Various Solutions to Cope with Difficulties, Teaching and Learning Environment Conditions, Various Intrinsic and Extrinsic Factors in Teaching, Barriers in Learning Literature Online, Varied Teaching Performance Status, Varied Learning Assessments, Improving Literature in Online Teaching Process and Effective Online Learning Recommendations. For the output of the study, a compilation of online literature for teachers and students was provided to serve and guide them in the process of teaching and learning online. It further helps them develop more fun and delightful learning of literature.

Keywords: experience, literature, literature teachers and students, new normal 


\section{Lived experience of literature teachers and students in the new normal}

\section{Introduction}

One of the most pressing public health concerns globally is the recent COVID-19 pandemic, which started in China and almost infected every country in the whole world. Though it affects people of all ages, it is most vulnerable to adults, children, and people with underlying medical conditions. As of this time, the number of infections and deaths is still increasing worldwide. The fights against threats on the COVID-19 pandemic were suffered profound effects and impacts in all sectors of the human race. These have resulted in widespread disruption such as travel restrictions, closure of schools, global economic recession, political conflicts, racism, and misinformation and controversies. One of the most affected has been the educational sector.

The current global changes, the growing importance of modern information and communication technology (ICT) pose enormous challenges for the new millennium, especially in education. To survive in this increasingly complex world and to be effective in the 21 st century, students become required more than ever to develop a wide range of competencies related to information, media, and technology with a range focus on skills such as intercultural skills, creativity, critical thinking, communication, and collaboration. Imparting these skills, in return, requires teachers to apply different teaching methods to help their learners realize such competencies and skills. The Philippines, just like any country in the world, needs to live in the new normal; if the virus is not contained, the Filipinos need to live with the disease as viruses are constantly evolving. Moreover, a new strain of the virus already emerged in the United Kingdom and Singapore. The list grows every day, which led to the banning of travelers. However, scientists are still on their way to studying and developing vaccines and presently in clinical trials (WHO, 2020). Therefore, for almost eleven (11) pandemic months, most countries worldwide and locally have temporarily closed educational institutions to contain the spread of the COVID-19 pandemic and reduce infections.

According to UNESCO (2020), it was stated that this closure had affected more than 1.2 billion learners worldwide, with more than 28 million learners in the. As expected, different countries worldwide have introduced various answers during the pandemic to continue the education process, one of them being the introduction of distance learning. These are online learning platforms such as google, TV broadcasts, guidelines, resources, video lectures, and the introduction of online. Thus, responses like community lockdown and community quarantine of several countries, including the Philippines, have led students and teachers to study and work from home, which led to the delivery of online learning platforms. However, online learning has posed different risks, problems, and challenges to both the teachers and students, especially in teaching and learning literature. It certainly means that literature teachers should implement several initiatives, methods, and techniques to equip their students with the knowledge and skills they need to live in this ever-changing technological world. Hence, literature remains a challenging field of study for both teachers and students for several valid reasons: reading long pieces of literature is such a tedious activity; it is only a means of teaching and learning language; some topics for study are not attractive; non-literature primary teachers do not know how to teach it, and some literary genres are challenging to study.

The shift to online learning can be difficult. Online teaching poses a different set of challenges for literature teachers and students as it can be difficult for teachers to teach online when they struggle to gauge how students are comprehending the subject content and whether they are participating in learning experiences. In addition, students have a limited time reading long literature pieces; limited individual and group activities; fewer students' participation and communication gap during the online discussion; lack of training and resources for literature teachers and students using the online modality.

Considering what is ahead, such concerns about the new generation's lack of motivation towards learning 
literature have exacerbated by the new century skills and current learning delivery in education. Hence, they have to equip their students to call for a renewed vision of literature education using that is centered on the ideals of a more refined approach that can equip students with the sensitivities and dispositions of the current world trend of globalization which is essential in developing global citizens.

The Department of Education (DepEd) has been implementing the new normal in education at the basic education, and strengthening educational planning and health has been its concern in providing quality, inclusive, and accessible education for every student. Hence, this study will be developed to provide a clear lens of the new normal in education as the situation presents a unique challenge to every teacher and student alike. Moreover, in her desire to help sustain the delivery of quality instruction to every school, the researcher presents the lived experiences of teachers and students in distance learning, specifically online learning, in selected private schools in Sto. Tomas, Batangas due to the COVID-19 pandemic. The present researcher has a keen interest in the current situation and challenges in the new normal education and how both the teachers and the students try to address their difficulties.

As a former teacher, the researcher has witnessed the difficulties in teaching literature, even in face-to-face instruction. Teaching and learning literature using online modality is something new to both teachers and students, which are undeniable challenges and difficulties that occur and has something to improve by many Literature teachers who would like to teach the best of their abilities but are hindered because of the challenges of distance learning modality using emerging technologies in literature education. The researcher is interested in finding out the challenges of distance learning modality, specifically online modality among Literature teachers and their students as they encounter and observe distance learning, and propose recommendations that can improve teaching literature in the new normal.

\subsection{Theoretical Framework}

This study is anchored on three theories: The Transactional Distance Theory of Dr. Michael G. Moore (1993 as cited in Larkin and Proctor, 2015), The Connectivism Theory of George Siemens (2004 as cited in Underwood, 2016), and David Kolb's (1984 as cited in Fromma, Radianti, Wehking, Stieglitz, Majchrzak, and Brockec, 2021) theory of Experiential Learning. The Transactional Distance Theory of Dr. Michael G. Moore (1993 as cited in Larkin and Proctor, 2015) suggested that transactional distance is the psychological and communications space that occurs between learners and is shaped by the learning environment and by the patterns of activity of individuals within the environment.

On the other hand, the Connectivism theory of George Siemens (2004 as cited in Underwood, 2016) is characterized as the learning theory of the digital age. One underlying assumption in this theory is that knowledge is distributed and can reside outside of ourselves. It is a model of learning that can guide first year advising through the integration of principles explored as chaos, network, and complexity, and self-organization theories as well as an understanding that decisions are based on rapidly altering foundations. It combines previous information with current information to create new meanings and understandings

Lastly, David Kolb's (1984 as cited in Fromma et al., 2021) defined the theory of experiential learning based on several fundamental models of experiential learning, including Lewin, Dewey, and Piaget, which basically refer to learning from experience or learning by doing. Learners immerse in a particular experience and reflect their experiences to develop new skills, attitudes, or ways of thinking. Experiential learning is defined as the process whereby knowledge is created through the transformation of experience. Knowledge results from combination of grasping and transforming experience.

The figure shown, the gathering of data conducted through interviews with the participants with structured interview questions and guides. The researcher used audio/video recording when interviewing and taking field notes. The participants were given the interview questions to elaborate on their lived experiences to determine the sociological concerns on the distance learning modality in teaching and learning literature, specifically the 
online learning modality. The researcher collated all the data from the interviews to be conducted, transcribed the interviews in verbatim with her twenty (20) participants. Afterward, she extracted the data from the transcription, categorize them by themes and clusters. The emerged themes were extracted from the responses of the participants.

Figure 1.

Conceptual Framework

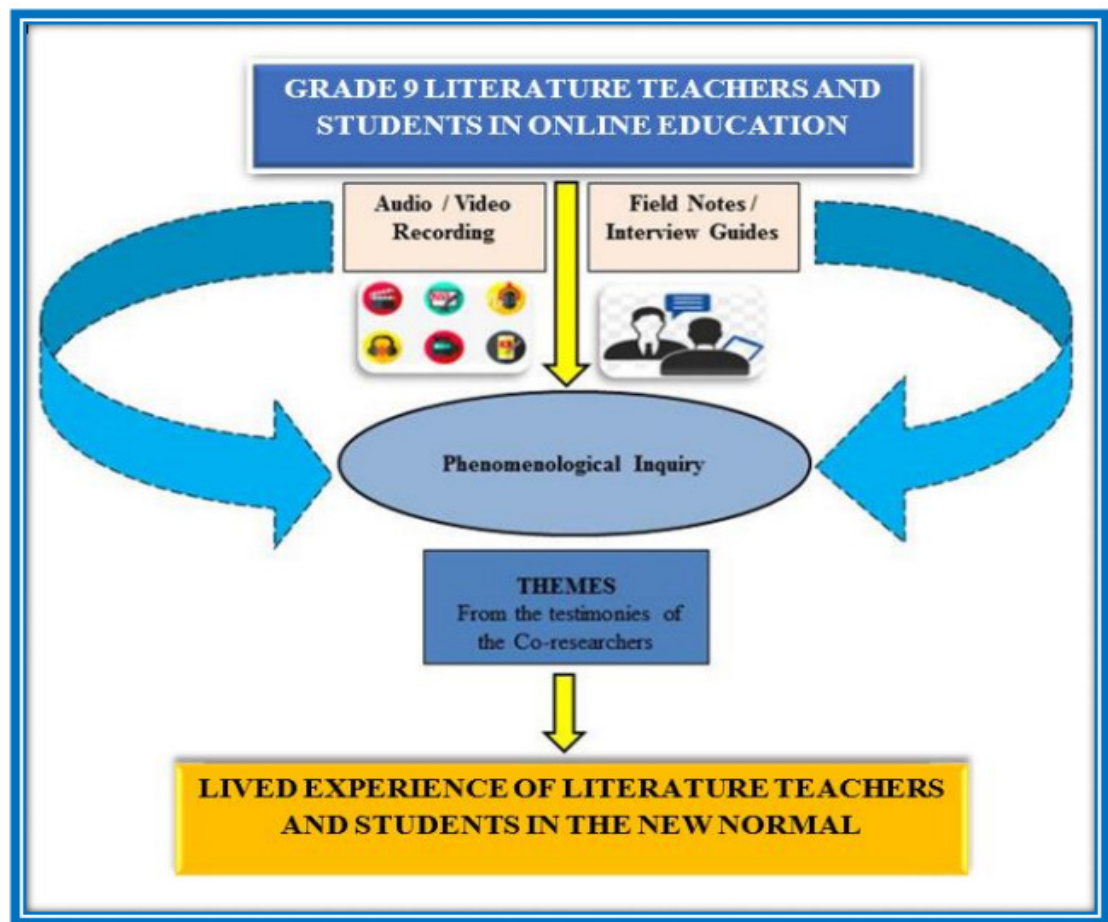

\subsection{Statement of the Problem/Central and Corollary Questions}

The researcher seeks to answer this central question: What is the essence of the lived experience of Literature teachers and students as regards Distance Learning modality, specifically online modality? And three Corollary Questions: 1. How do the teachers and the students describe their experiences in using online modality in teaching and learning literature? 2. What themes emerge from the testimonies of Literature teachers and students? 3. Based on the findings of the study, what recommendations may be proposed to help improve the teaching and learning literature and ensure quality distance learning education?

\subsection{Scope and Delimitations}

The study looked into the problems and challenges on the lived experience of the teachers and students in the new normal. The study was limited to the ten (10) literature teachers and ten (10) of their students. The line of questioning during the interview was limited to the purpose of extracting the themes that will arise from the study regarding the three types of interaction in literature education, the challenges and problems encountered by the participants as regards to Distance Learning modality in using online technologies in teaching and learning literature.

\section{Review of Related Literature and Studies}

A significant distinction of this study from the other previous studies is that it concentrates on the consequences of emerging technologies in distance learning modality based on the experience of literature teachers. It will provide information about how teachers can support motivation and success in online settings through effective communication and instruction. Using online platforms for students to direct their learning can 
support motivation by making students feel empowered, successful, interested, and cared for. Additionally, students need to understand the usefulness of the topic and how the themes are relevant to their own lives. This study points out ways to improve teaching and learning of literature through emerging technologies in distance learning modality, specifically online.

\section{Methodology}

\subsection{Research Design}

This research study was conducted to explore the lived experiences of literature teachers and students in the new normal. The research design used was qualitative with the phenomenological approach. Grade 9 Literature Teachers and students were the focus of this research undertaking because they were the ones who completely observed and experienced the distance learning modality, specifically online. The participants came from the four private schools, His Care Christian Institute, St. Thomas Academy, St. Thomas Montessori Learning Center and Tanauan Institute. All Grade 9 Literature teachers totaling to ten and ten students were interviewed by the researcher. Since the research used the qualitative method with an Interpretative Phenomenological Analysis, the researcher employed the purposive sampling in choosing her participants.

\subsection{Research Instrument}

The instrument in this study was the researcher-made ten (10) interview questions that derive as what's and how's regarding the experiences of the grade 9 literature teachers and students in the private schools. It was reviewed by an adviser and validated by the three research experts composed of grammarians, qualitative research experts, and school heads to ensure the correctness of the questions conducted during the interview.

\subsection{Respondents/Participants of the Study}

The participants of the study were Grade 9 Literature teachers and Grade 9 students from selected Junior High Schools in the private schools of Batangas, specifically, St. Thomas Academy, St. Thomas Montessori Learning Center, His Care Christian Institute, and Tanauan Institute. In particular, three (3) teachers and three (3) students from St. Thomas Academy, three (3) teachers and three (3) students His Care Christian Institute, two (2) teachers and two (2) students from St. Thomas Montessori Learning Center, two (2) teachers and two (2) students from Tanauan Institute were interviewed based on the time the researcher and participants agreed upon.

\subsection{Data Gathering Procedure}

The researcher asked for the consent of the School Division Superintendent's of and Principal's offices. Letters written permission submitted to individual school administrator/s and teachers of the chosen schools. The objectives are clearly stated in the letter of request and indicated that the participants' responses were kept confidential. It was sent online (Gmail) to observe social distancing. After the approval, the researcher scheduled the interview session. The researcher prepared the self-made interview questionnaire, recorders, and camera for recording purposes. The researcher communicated with the participants through google meet to discuss the importance and objectives of the study, the copies of the questions using google forms and sheets in google classroom, and the ZOOM app for the interviews.

Data collected were subject to appropriate transcription, conversion, and coding. Also, the teachers were asked to provide sample print-outs of the learning materials that they use in teaching poetry inside the classroom. This was done with permission from the participants and was subjected to analysis and data-gathering which was used to finalize the interview questions. After collecting the data using the interview, the researcher proceeded to the next part which was the transcription of the responses. After the transcription, the researcher encoded, and then transcribed the responses and these were subjected to analysis to formulate themes. 


\subsection{Treatment of Qualitative Data}

After gathering all the data coming from the interviews that were conducted, the researcher transcribed the interviews verbatim. Afterwards, she extracted the similar responses of her coresearchers, categorized them by themes, codes, and clusters. The emerging themes will be extracted from the similar responses per line of the verbatim transcription. This process was called the interpretative phenomenological analysis (IPA).

\section{Results and discussion}

Based on the data gathered, there are thirteen (13) themes that emerged from the different responses of the Grade 9 Literature Teachers and students about their experiences in the new normal:

4.1 What is your idea of Distant Learning Modality, specifically online education, before you were required to use it in teaching (for teachers) or in learning (for students)?

\section{Thematic Chart A}

Diverse Perspectives

\begin{tabular}{|c|c|c|}
\hline Participant & Responses & Subordinate Themes \\
\hline Teacher Renzo & $\begin{array}{l}\text {... I thought it would be easy for both the teachers and the } \\
\text { learners }\end{array}$ & Easy \\
\hline Student Danielle & $\begin{array}{l}\text { Para po sa akin ang idea ko dito ay ahhh magiging madali po ang } \\
\text { pag aaral ... }\end{array}$ & \\
\hline Teacher Doty & $\begin{array}{l}\text {... students can still acquire learning without having ahhhh a } \\
\text { physical contact with the teacher }\end{array}$ & $\begin{array}{l}\text { Learning without Physical } \\
\text { Contact }\end{array}$ \\
\hline Teacher Mark & $\begin{array}{l}\text {... give programs to students who don't want to go to school but } \\
\text { wants to continue learning through the use of online discussion } \\
\text { and online platforms. }\end{array}$ & \\
\hline Teacher Kenneth & $\ldots$ to teach students online, ... & \\
\hline Teacher Mischelle & ... basically ahhmmm we took classes online. & \\
\hline Student Charisse & $\begin{array}{l}\text {... maganda kasi hindi na po namin kailangan pumuntang ahhh } \\
\text { sa paaralan lalo na po na mayroon pang pandemic ... }\end{array}$ & \\
\hline Teacher Ron & $\ldots$ a good platform for distance learning ... & Good Platform \\
\hline Teacher Jasmine & $\ldots$ an alternative way of ahmmm DEPed. ... & Aternative Modality \\
\hline Student Marga & $\begin{array}{l}\text {... Dito po ang mga estudyante ay gagamit ng kanilang mga } \\
\text { gadgets upang makapasok sa klase ... }\end{array}$ & Use of Technology \\
\hline Student Joydel & ...ang pagka-klase sa pamamagitan ng technology... & \\
\hline Student Redge & $\begin{array}{l}\text { paraan na nakalap ng gobyerno at DEPED upang ipagpatuloy po } \\
\text { ang pag-aaral sa taong ito.... }\end{array}$ & Govt. and DEPED way \\
\hline Student Sean & $\begin{array}{l}\text {...isang paraan ng mga international students kung gusto po nila } \\
\text { magaral ng English dito sa Pilipinas. }\end{array}$ & $\begin{array}{l}\text { Way for International Students } \\
\text { to learn }\end{array}$ \\
\hline Student Althea & ...may naitutulong po ito para umusad ang edukasyon. ... & Helpful \\
\hline Student Jaymark & ... bago ko ito gamtin ay hindi ito magiging madali ... & Not Easy \\
\hline Teacher Joy & .... could be a burden ehhh ... & Burden \\
\hline Teacher Rosh & ahhhh my idea is that it can be a challenging prospect ... & Challenging \\
\hline Student Nelson & ...isang napakahirap na proseso sa mga estudyante ... & \\
\hline Student Ruzzle & Ahhh Kumplikado po sapalagay ko ang distance learning po ... & Complicated \\
\hline
\end{tabular}

With a theme, Diverse Perspectives, most participants said that distance learning modality, specifically online, was Learning without Physical Contact because they believed that they could facilitate teaching and learning without physical interaction between them. Two participants stated that it could be Easy because they sit and face in front of their gadgets. Other participants divulged that it was a Good Platform and Helpful during this pandemic as they do not need to travel to school. Also, it was a Way for International Students to Learn. Moreover, another two participants mentioned that it needed the Use of Technology as learning conducted through online applications. On the other hand, some participants stated that it was Government and DepEd Way to continue school classes and Alternative Modality because they believed it was just a temporary solution to the Philippine Education System. In addition, some of the participants mentioned that it could be Not Easy, Burden, Complicated, and Challenging as this modality was new to them, and they do not have any 
background knowledge on how to deal with it.

Distance learning modality is the new normal setting of education in the Philippines and most countries because of the Covid-19 pandemic. Today, the classroom is a home, and the learning spaces wherein the teaching-learning processes are the learning delivery modalities that provide safe methods where education can still foster and succeed. Thus, education will find its space even amid a persistent pandemic as it is a necessity for every Filipino. In addition, Education is most vital when there is sharing and hearing of diverse perspectives and voices in a setting of learning and development. Therefore, a rich educational opportunity is available to those who can produce an environment in which varying ideas and insights build on broad backgrounds.

In connection, Jong (2020) stated that schools started rapidly transitioning towards remote online learning as the only logical solution with a focus on teaching and learning activities without any need for physical presence. And although computer-based and online learning has been around for decades, it wasn't easy to implement a campus-wide transition on such short notice. Taskforces for distance learning were appointed, and through technical and organizational trial and error, lectures were transformed into webinars and small group sessions into virtual classrooms. Due to the limited amount of time available, efforts were mainly focused on activities that can be implemented quickly. Schools entered an emergency remote teaching mode in order to keep their students going.

\subsection{What are your thoughts and feelings about teaching (for teachers) and learning (for students) literature online?}

\section{Thematic Chart B}

Different Viewpoints

\begin{tabular}{|c|c|c|}
\hline Participant & Responses & Subordinate Themes \\
\hline Teacher Mischelle & ... it's a big challenge for us teachers ... & Challenging \\
\hline Teacher Kenneth & $\ldots$ very challenging $\ldots$ & \\
\hline Teacher Mark & $\begin{array}{l}\text {... challenging since it involves a lot of story from different } \\
\text { authors.... }\end{array}$ & \\
\hline Teacher Jasmine & The transition to online learning is not really smooth ... & Not smooth \\
\hline Teacher Joy & $\ldots$ kind of difficult.... & Difficult \\
\hline Teacher Ron & ... so probably it's kinda difficult ... & \\
\hline Teacher Rosh & ... burdensome and at the same time not satisfying eh. ... & Burdensome \\
\hline Student Ruzzle & Mahirap po ... & \\
\hline Student Danielle & Sa ngayon po nahihirapan po ako. ... & Hard \\
\hline Student Joydel & ...napakahirap ... & \\
\hline Student Jaymark & Para sa akin mahirap ... & \\
\hline Student Charrise & ... ito ay napakahirap pag-aralan lalao na kung online .... & \\
\hline Student Nelson & ...walang kakayahan na mag online class .... & Not capable \\
\hline Teacher Doty & "To be honest I 'am against online learning eh ..." & $\begin{array}{l}\text { Against Towards Online } \\
\text { Learning }\end{array}$ \\
\hline Student Marga & Medyo nakakadismaya lamang po ... & Disappointed \\
\hline Teacher Renzo & Teaching literature requires time and effort to teach and learn. & Required of Time and Effort \\
\hline Student Althea & $\begin{array}{l}\text { Para sa akin po naging sapat po ang pagaaral namin ng } \\
\text { panitikan online. ... }\end{array}$ & Contented \\
\hline Teacher Howell & $\ldots$ its easier $\ldots . .$. & Easy \\
\hline Student Sean & Convenient ... & Convenient \\
\hline
\end{tabular}

With a theme, Different Viewpoints, most participants shared that online learning was Challenging, Hard, Difficult, and Burdensome as the students and teachers were not prepared for this new learning modality. Some participants divulged that the transition was Not Smooth because of many issues before and during the process. Another mentioned of Not Capable to continue Online learning because of financial matters during this pandemic. Likewise, some participants came up with different ideas such as Against towards Online Learning, Disappointed, and Required Time and Effort. However, three participants shared that it was Easy, Convenient, and Contented because they could learn without going to school. 
Pordunzalan, R.

Rapanta et al. (2020) stated that the term 'online learning' is widely used but with a variety of meanings. Online learning refers to learning that is mediated by the Internet. It is wider than 'networked learning'; while networked learning focuses on human-human connections, online learning lacks such specificity.

\subsection{How did you prepare for teaching (for teacher) or learning (for students) literature online?}

\section{Thematic Chart C}

Various Preparations

\begin{tabular}{|c|c|c|}
\hline Participant & Responses & Subordinate Themes \\
\hline Teacher Kenneth & I do a lot of research ... & Researched \\
\hline Teacher Rosh & $\begin{array}{l}\text { Well I do a lot research to get prepared in the topic in } \\
\text { literature. ... }\end{array}$ & \\
\hline Teacher Kenneth & $\ldots$ to be honest I research, I ask my co-teachers .... & \\
\hline Teacher Joy & $\ldots$ I do a lot of research and study the literature... & \\
\hline Teacher Ron & I do a lot of research ... & \\
\hline Teacher Howell & ... after pong mag prepare and syempre ahhhh reading time... & Reading Time \\
\hline Teacher Doty & $\ldots$ starting it from myself the motivation... & Motivation \\
\hline Teacher Mark & $\begin{array}{l}\ldots . \text { I put much energy for my students in telling different stories } \\
\text { and asked them more questions ... }\end{array}$ & Being Energetic \\
\hline Teacher Howell & ... I prepare PowerPoint presentation in teaching. & Prepred Teaching Materials \\
\hline Student Sean & $\begin{array}{l}\text { Ang ginawa ko po ay kinumbinsi ko ang aking pamilya na } \\
\text { magpakabit ng wi-fi sa bahay ... }\end{array}$ & Asked Family Support \\
\hline Student Danielle & $\begin{array}{l}\text {... natutulog po ako ng maaga upang maaga din po akong } \\
\text { makaligo... }\end{array}$ & Slept Early to prepare \\
\hline Student Ruzzle & ... hindi ako ganon naghanda ... & No preparation \\
\hline Student Marga & Wala naman po akong ginawang paghahanda.... & \\
\hline Student Charrise & hindi po talaga ako palahandang tao & \\
\hline Student Nelson & Sa totoo lang hindi ko po ito pinag handaan ... & \\
\hline Student Joydel & $\begin{array}{l}\text {... pamamagitan po ng pagbabasa ng mga artikulo tungkol sa } \\
\text { literatura at mga kahalagahan nito. ... }\end{array}$ & Advanced Reading \\
\hline Student Jaymark & Nagbasa-basa lang po ako sa internet & \\
\hline Student Redge & $\begin{array}{l}\text {... ako po ay dinownload ko po ang mga application na } \\
\text { kakailanganin }\end{array}$ & $\begin{array}{l}\text { Downloaded Necessary } \\
\text { Applications }\end{array}$ \\
\hline Student Althea & $\begin{array}{l}\text { Sinisigurado ko po muna na kumpleto ang mga gagamitin ko } \\
\text { po sa pag-aaral nito. ... }\end{array}$ & $\begin{array}{l}\text { Assured completeness of } \\
\text { learning materials }\end{array}$ \\
\hline
\end{tabular}

With a theme, Various Preparations, the teacher and learner-participants came up with different means in preparing the teaching and learning of literature online. They elaborated these preparations such as had Researched, Reading Time, Motivation, Being Engertic, Prepared Teaching Materials, Asked for Family Support, Slept Early to Prepare for Online Class, Advanced Reading, Downloaded Necessary Applications, and Assured Completeness of Learning Materials. On the other hand, four participants said that they had No Preparations.

According to Eden-online.org (2020) stated that students, parents and teachers realised that previous training and preparations were never geared towards online teaching and learning. The programmes and curricula were more oriented to the traditional forms of teaching and learning, usually with a small percentage of digital technologies. Students were all keen on going back to campuses, to meet with their peers and teachers, especially freshmen who did not have time to get acquainted with the new academic environment. And yet despite the massive disruptions caused to the educational system, students recognised the benefits of online education in flexibility, availability of learning materials, possibilities of enhanced communication, wider connections and engagement with others as well as mobility. In sum, it has become clear that online learning can empower students at all levels of education.

\subsection{What adjustments did you make in teaching (teachers) or learning (students) literature online?}

With a theme, Various adjustments, the teacher and student-participants came up with different ways in adapting to the teaching and learning of literature online. They mentioned these adjustments: Time 
Management, Established New Teaching Routines, Researched, Asked Help from Family, Being committed, and Independent Learning. On the other hand, four participants said that they had No adjustment.

\section{Thematic Chart D}

Various Adjustments

\begin{tabular}{|c|c|c|}
\hline Participant & Responses & Subordinate Themes \\
\hline Teacher Kenneth & Syempre ahhh adjustment on time ..." & Time Management \\
\hline Teacher Jasmine & $\ldots$ when it comes to time management $\ldots$ & \\
\hline Teacher Mark & $\begin{array}{l}\text { I've always consider the time that will run from my lesson } \\
\text { especially in teaching literature. ... }\end{array}$ & \\
\hline Teacher Rosh & $\begin{array}{l}\ldots \text { The timeframe off the lesson plan will be cut in order to } \\
\text { reach the minimum screen time of the student... }\end{array}$ & \\
\hline Student Nelson & ... naglaan po ako ng oras sap ag-aaral ..... & \\
\hline Teacher Mischelle & ... establish new routines in teaching. & $\begin{array}{l}\text { Established new teaching } \\
\text { routines }\end{array}$ \\
\hline Teacher Joy & $\begin{array}{l}\text {... I've thought of a new way on how to engage students in our } \\
\text { discussion especially ... }\end{array}$ & \\
\hline Teacher Jasmine & $\begin{array}{l}\text { Most of the time I am researching talaga and spending my time } \\
\text { in front of my laptop and look and prepare for the lesson ... }\end{array}$ & Researched \\
\hline Teacher Doty & $\begin{array}{l}\text { In regards to adjustments ahhh I ask help from my daughter } \\
\text { because I am not techy eh. ... }\end{array}$ & Asked help from family \\
\hline Student Marga & $\begin{array}{l}\text {... nagpaturo pa po ako sa aking kapatid upang higit na mas } \\
\text { maunawaan ito. }\end{array}$ & \\
\hline Student Althea & $\begin{array}{l}\ldots \text { at humihingi ako ng tulong sa aking pamilya kung may mga } \\
\text { bagay akong hindi maunawaan. }\end{array}$ & \\
\hline Student Sean & $\begin{array}{l}\text { Sinuguro po namin may maayos na internet connection at } \\
\text { maging mas committed po sa gawain na ipapagawa ng aming } \\
\text { guro. }\end{array}$ & Being committed \\
\hline Student Redge & $\begin{array}{l}\text { Sa pansarili ko po nagbasa-basa lang po ako gamit ang internet } \\
\text { at inintindi kop o yung proseso ng pag-aaral namin ngayon ... }\end{array}$ & Independent Learning \\
\hline $\begin{array}{l}\text { Teacher Ron } \\
\text { Teacher Howell }\end{array}$ & $\begin{array}{l}\text {... I really don't have any adjustments in teaching literarure.. } \\
\text {... I don't have adjustment talaga ahmmmm siguro ... }\end{array}$ & No adjustment \\
\hline
\end{tabular}

In view of Besser, Flett, and Hill (2020), a key component of adaptability is the belief that one has or can develop the capacity to be adaptable and can demonstrate this capability. Students who are relatively low in adaptability need to embrace a possible self that includes being able to adjust well to new and uncertain circumstances. It is known from work on the promotion of possible selves that the develop-ment of a positive possible self is more likely when certain factors are in place and these factors seem highly relevant to promoting a sense of being adaptable. These factors include plausible strategies and resources, a fit with their sense of who students are in terms of their core identities, and supportive relationships that encourage the development of the possible self.

\subsection{What challenges did you encounter in teaching (for teachers) or learning (for students) literature online?}

\section{Thematic Chart E}

\section{Distinct Challenges}

\begin{tabular}{|c|c|c|}
\hline Participant & Responses & Subordinate Themes \\
\hline Teacher Ron & $\begin{array}{l}\ldots \text { there are so many information's on the web so I got so } \\
\text { confuse about ... }\end{array}$ & Information Confusion \\
\hline Teacher Renzo & $\begin{array}{l}\text { I even question myself most of the time like how can I teach it } \\
\text { online? .... Another thing is my knowledge of technological } \\
\text { tools ... }\end{array}$ & $\begin{array}{l}\text { Self-Doubt and Lack of } \\
\text { Technological Knowledge }\end{array}$ \\
\hline Teacher Mischelle & ...the students are not that knowledgeable to online ... & \\
\hline Teacher Doty & $\begin{array}{l}\ldots \text { I am not that familiar on how to use the functions in some } \\
\text { applications like zoom or google classroom ... }\end{array}$ & $\begin{array}{l}\text { Unfamiliarity with online } \\
\text { applications }\end{array}$ \\
\hline Teacher Rosh & $\ldots$ application of technology in my materials. .... & \\
\hline Teacher Howell & $\begin{array}{l}\ldots \text { nobody answer me even I provide and told them to read. } \\
\text { Basically, the internet connection of the students... }\end{array}$ & Uncooperative Students \\
\hline Teacher Joy & $\begin{array}{l}\text { It's the students who are not in front of their devices when I the } \\
\text { teacher is discussing the lesson. }\end{array}$ & \\
\hline
\end{tabular}


Pordunzalan, R.

\begin{tabular}{|c|c|c|}
\hline \multicolumn{3}{|l|}{ Continued ... } \\
\hline Teacher Jasmine & $\begin{array}{l}\ldots \text { there are times that ahhhhm ahhh ang tagal nila mag respond } \\
\text { so yun. ... }\end{array}$ & Late students response \\
\hline Teacher Mark & $\begin{array}{l}\text { Usually it's more on technical difficulties like audio problem } \\
\text { and loss of internet connection. }\end{array}$ & Technical difficulties \\
\hline Teacher Kenneth & ...maybe my connection or my students connection. & Unstable Internet Connection \\
\hline Student Ruzzle & $\begin{array}{l}\ldots \text { paghina ng signal ng connection naming mga estudyante at } \\
\text { minsan ng guro pati narin po ang ingay ng kapaligiran ... }\end{array}$ & \\
\hline Student Charrise & $\begin{array}{l}\text { Ah kapag po mahina ang internet wala ka pong maiintindihan } \\
\text { kasi paputo-putol po.... }\end{array}$ & \\
\hline Student Danielle & $\begin{array}{l}\text { Karaniwan po eh ang madalas po ay ang mabagal na internet } \\
\text { connection ,", }\end{array}$ & \\
\hline Student Joydel & $\begin{array}{l}\text {,, pawala-walang internet connection tapos po kung meron } \\
\text { man ay yung temptation po sa online games ,, }\end{array}$ & \\
\hline Student Jaymark & $\begin{array}{l}\text { May mga panahon na ang internet ay hindi nakikisabay sa amin } \\
\text { at ito ay bumabagal ... }\end{array}$ & \\
\hline Student Sean & $\begin{array}{l}\ldots \text { distractions po na dulot ng social media, new movies po at } \\
\text { series ng anime at online games po ... }\end{array}$ & $\begin{array}{l}\text { Distractions from Online } \\
\text { Applications }\end{array}$ \\
\hline Student Nelson & $\begin{array}{l}\text { Kawalan nang internet at pag loloko po nang aking cellphone } \\
\text {.. kawalan ng kapasidad ng aking laptop na pagsabay sabayin }\end{array}$ & Defective Learning Equipment \\
\hline Student Marga & $\begin{array}{l}\text { ang mga bagay na kailangan ko gawin. Isa rin po pala ang } \\
\text { gastos sa load dahil wala po kaming wi-fi. }\end{array}$ & \\
\hline Student Althea & $\begin{array}{l}\text {.... na nangangailangan ng ugnayan sa mga ka-grupo na hindi } \\
\text { po namin natatapos ang mga aktibidad dahil minsan po walang } \\
\text { reply o hindi po agad nasagot ang aking mga kagrupo ... }\end{array}$ & $\begin{array}{l}\text { Irresponsible and Unresponsive } \\
\text { Classmates }\end{array}$ \\
\hline Student Redge & $\begin{array}{l}\text { Batay sa mga hamon na kinaharap ko sa panitikan online, dito } \\
\text { na pumapasok ang aspeto ng kalusugan. ... }\end{array}$ & Health Condition \\
\hline
\end{tabular}

With a theme, Distinct Challenges, the teacher and learner-participants came up with different challenges in teaching and learning literature online. The majority of the participants divulged that it was the Unstable Internet Connection as it happened often, and not all had strong signals because of different locations. Moreover, some of the participants shared these challenges: Information Confusion as there were many details on the internet with different authors and versions of literary pieces. Self-Doubt and Lack of Technical Knowledge because they believed that they were not confident and had limited knowledge of using technology and Unfamiliarity with Online Applications as they were new with the tools and applications used. Also, some of the participants shared different challenges such as Uncooperative Students, Late students' response, Technical difficulties, Distractions from Online Applications, Defective Learning Equipment, Irresponsible and Unresponsive Classmates, and Health conditions.

In connection, Kebritchi (2017), online learning faces many challenges ranging from learners' issues, educators' issues, and content issues. It was a challenge for institutions to engage students and participate in the teaching-learning process. It was challenging for teachers to move from offline mode to online mode, changing their teaching methodologies and managing their time. It was challenging to develop content which not only covered the curriculum but also engage the students. The quality of e-learning programs was a real challenge. There was no clear stipulation by the government in their educational policies about e-learning programs.

\subsection{How did you face and resolve such issues/challenges?}

With a theme, Various Solutions to Cope with Difficulties, participants came up with different means of dealing with their difficulties. Since participants were from different locations and had different teaching and learning environments, they developed various solutions. They elaborated these strategies into: Being resourceful, Uploaded Learning Materials and Presentations, Called the Internet Provider, Had Anti-Radiation Glasses, Find Place with a Strong Signal, Got Connection from the Neighborhood, disconnected other Gadgets, Communication with Classmates, Communication with Teacher, Being perseverant, Regular Student Monitoring, Encouraged Students, Motivating Oneself, Service and Equipment Upgrade, Bought New Teaching Equipment, Asked help from co-teacher.

In connection, Dhawan (2020) stated that a lot of issues are attached to online education but they cannot 
ignore the perks of it in times of such crisis. They can always have solutions to fix these difficulties. Technical difficulties can be solved through prerecording video lectures, testing the content, and always keeping Plan B ready so that the teaching-learning process cannot be hampered. Online courses should be made dynamic, interesting, and interactive. Teachers should set time limits and reminders for students to make them alert and attentive. Efforts should be made to humanize the learning process to the best extent possible. Personal attention should be provided to students so that they can easily adapt to this learning environment. Social media and various group forums can be used to communicate with students. Communication is the key when it gets difficult to try reaching out to students via texts, various messaging apps, video calls, and so on content should be such that enable students for practice and also hone their skills. They need a high level of preparedness so that they can quickly adapt to the changes in the environment and can adjust themselves to different delivery modes.

\section{Thematic Chart F}

Various Solutions to Cope with Difficulties

\begin{tabular}{|c|c|c|}
\hline Participant & Responses & Subordinate Themes \\
\hline Teacher Ron & Ah well I am a very resourceful person .. & Being resourceful \\
\hline Teacher Joy & $\begin{array}{l}\ldots, \text { usually I upload videos of our topics in the LMS especially } \\
\text { the presentation that I used ... }\end{array}$ & $\begin{array}{l}\text { Uploaded Learning Materials } \\
\text { and presentations }\end{array}$ \\
\hline Student Jaymark & $\begin{array}{l}\text { Minsan ay itinatawag namin ito sa mga mang-gagawa ng } \\
\text { galaxy ... }\end{array}$ & Called the Internet Provider \\
\hline Student Redge & ... nagpabili po ako ng anti-radiation glass ... & Had Anti-Radiation Glasses \\
\hline Student Ruzzle & $\begin{array}{l}\text { Ako po ay humanap ng lugar na may malakas na signal at kung } \\
\text { minsan ay pinagsasabihan ang mga maiingay sa aking paligid. }\end{array}$ & Place with strong signal \\
\hline Student Nelson & $\begin{array}{l}\text { Sa kawalan nang internet naki connect nalang po ako sa kapit } \\
\text { bahay .... }\end{array}$ & $\begin{array}{l}\text { Got connection from } \\
\text { neighborhood }\end{array}$ \\
\hline Student Danielle & $\begin{array}{l}\text { pag diskonek ng ibang cellphone sa bahay na naka konek sa } \\
\text { aming wifi ... }\end{array}$ & Disconnected other gadgets \\
\hline Student Charrise & $\begin{array}{l}\text {,, nagtatanong tanong na lang po ako sa aking mga kamag aral } \\
\text { kung ano ang napag-aralan noong mga oras na iyon. ... }\end{array}$ & $\begin{array}{l}\text { Communication with } \\
\text { classmates }\end{array}$ \\
\hline Student Althea & $\begin{array}{l}\ldots . \text { nakahanap po ako ng solusyon sa pakikipag-ugnayan sa } \\
\text { aking mga kagrupo .... }\end{array}$ & \\
\hline Student Joydel & $\begin{array}{l}\text {... nagsasabi na lang po sa aming guro at huihingi na lang po } \\
\text { ng materyales na ginamit sa pagaaral tapos binabasa ko na lang } \\
\text { po yun at iniintindi .... }\end{array}$ & Communication with Teacher \\
\hline Student Marga & $\begin{array}{l}\text {... po pinagtyatyagaan ko na lamang po ito sa abot ng aking } \\
\text { makakaya... }\end{array}$ & Being perseverant \\
\hline Teacher Renzo & $\begin{array}{l}\text { I regularly check the status of the students through the } \\
\text { parents ... }\end{array}$ & Regular Student Monitoring \\
\hline Teacher Mischelle & $\begin{array}{l}\text {... I let my students to ask question if they are encountering } \\
\text { some difficulties ... }\end{array}$ & \\
\hline Teacher Jasmine & $\begin{array}{l}\text { In resolving such issues as much as possible I encourage the } \\
\text { students to turn on their cam ... }\end{array}$ & Encouraged Students \\
\hline Teacher Howell & $\ldots$ I am giving them the opportunity ... & \\
\hline Teacher Kenneth & Ayon, Uhhhm number 1 talaga you have to motivate yourself." & Motivating Oneself \\
\hline Student Sean & $\begin{array}{l}\text {.... kaya po ang ginagawa ko ay minomotivate ko na lang po } \\
\text { ang sarili ko na making ... }\end{array}$ & \\
\hline Teacher Rosh & $\begin{array}{l}\text { Well the connection I upgraded my connection to fiber } \\
\text { connection ... }\end{array}$ & $\begin{array}{l}\text { Service and Equipment } \\
\text { Upgrade }\end{array}$ \\
\hline Teacher Mark & $\begin{array}{l}\text { I bought a new headphone that's the only thing I can afford for } \\
\text { the meantime ... }\end{array}$ & Bought new teaching equipment \\
\hline Teacher Doty & Basically I ask my co-teachers about those matters... & Asked help from co-teacher \\
\hline
\end{tabular}

\subsection{How do you describe the learning environment in teaching (for teachers) and learning (for students) of}

literature through online education?

With a theme, Teaching and Learning Environment Conditions, most participants said that there was a Presence of Environmental Distractions and Uncomfortable Environment as it showed that they took attention away from what was needed to do when listening to the class. Likewise, some of the participants came up with different views on the ambiance of their teaching and learning environment. Some participants divulged 
Pordunzalan, R.

that they had Limited Resources, No Proper Learning Equipment, and Inappropriate Teaching and Learning Place. In contrast, three participants mentioned that they had Convenient Teaching and Learning Environment.

\section{Thematic Chart G}

Teaching and Learning Environment Conditions

\begin{tabular}{|c|c|c|}
\hline Participant & Responses & Subordinate Themes \\
\hline Teacher Ron & ... comes to online modality its very limited. & Limited resources \\
\hline Teacher Renzo & $\begin{array}{l}\ldots, \text { there are unnecessary noises that can distract me and my } \\
\text { students ... }\end{array}$ & $\begin{array}{l}\text { Presence of Environmental } \\
\text { Distractions }\end{array}$ \\
\hline Teacher Joy & $\begin{array}{l}\ldots . \text { There will be the noises of animals like dogs and chickens } \\
\text { and also car horns. }\end{array}$ & \\
\hline Teacher Mischelle & $\begin{array}{l}\ldots \text { it is a little bit noisy since there are five teachers in our } \\
\text { room ... }\end{array}$ & \\
\hline Student Danielle & Medyo maingay at magulo po sa aming tahanan ... & \\
\hline Student Joydel & $\begin{array}{l}\text { Kulang at hindi po sapat ang espasyo at maingay na } \\
\text { kapaligiran ... }\end{array}$ & \\
\hline Student Marga & $\begin{array}{l}\text { Mahirap po intindihin dahil po hindi maiiwasan ang ingay na } \\
\text { nakakaistorbo sa aking pag-aaral. }\end{array}$ & \\
\hline Teacher Doty & $\begin{array}{l}\ldots \text { its not really comfortable } \ldots \\
\text { Uncomfortable Learning Environment }\end{array}$ & Uncomfortable Environment \\
\hline Teacher Mark & $\ldots$ is it's uncomfortable ... & \\
\hline Teacher Howell & The word that I can give is uncomfortable ... & \\
\hline Student Sean & Hindi po komportable .... & \\
\hline Student Althea & $\begin{array}{l}\text { Masasabi ko po na hindi po ako kumportable at mayroon pong } \\
\text { mga distraksyon sa paligid .... }\end{array}$ & \\
\hline Student Nelson & $\begin{array}{l}\text { Sa kondisyon kop o ay hindi po maayos at hindi } \\
\text { komportable .... }\end{array}$ & \\
\hline Student Charrise & $\begin{array}{l}\text {... wala po akong matinong lamesa na maaring pagpatungan ng } \\
\text { aking mga gamit at pagsulatan ... }\end{array}$ & No Proper Learning equipment \\
\hline Teacher Kenneth & $\begin{array}{l}\ldots \text { I think yeah the teaching environment para sakin is } \\
\text { convenient naman siya. }\end{array}$ & $\begin{array}{l}\text { Convenient Teaching and } \\
\text { Learning Environment }\end{array}$ \\
\hline $\begin{array}{l}\text { Student Redge } \\
\text { Student Jaymark }\end{array}$ & $\begin{array}{l}\ldots \text { maayos at tamang-tama sa online na edukasyon ... } \\
\ldots \text { sadyang naglaan ng study area ... }\end{array}$ & \\
\hline Teacher Rosh & $\begin{array}{l}\ldots \text { not appropriate because it's my personal room eh and it's } \\
\text { not a workplace ... }\end{array}$ & $\begin{array}{l}\text { Inappropriate Teaching and } \\
\text { Learning Place }\end{array}$ \\
\hline Teacher Jasmine & .. not the appropriate place eh ... & \\
\hline Student Ruzzle & Hindi po naangkop at hindi po ... & \\
\hline
\end{tabular}

Prameswari and Budiyanto (2017) identified that effective teaching requires the harmony between individual teachers' characteristics and the support of school administrators. In a hand, teachers are accounted for specific attributes such as well-prepared teaching materials and personal experience in teaching and delivery.

\subsection{What are the internal and external factors that influence the quality of teaching (for teachers) and learning} (for students) literature online?

\section{Thematic Chart H.1}

Various Intrinsic and Extrinsic Factors in Teaching

\begin{tabular}{|c|c|c|}
\hline Participant & Responses & Subordinate Themes \\
\hline Teacher Mischelle & $\begin{array}{l}\text { Internal factor is the motivation and perception } \ldots \text { For the } \\
\text { external factors is the environment and the resources } \ldots\end{array}$ & Motivation and Environment \\
\hline Teacher Renzo & $\begin{array}{l}\text { For external factor, } \ldots \text { the environment... while in the internal } \\
\text { aspect is the motivation and the message of the lesson ... }\end{array}$ & \\
\hline Teacher Jasmine & It's the ano eh your motivation and effort ... & \\
\hline Teacher Joy & $\begin{array}{l}\text { For the internal are the technology and book resources ... the } \\
\text { mood of the students and their willingness to learn. While for } \\
\text { the External are noises, culture inside the house, household } \\
\text { chores }\end{array}$ & Willingness \\
\hline Teacher Ron & $\begin{array}{l}\text {...internal factors ... interest } \ldots \text { Pero yung sa External factors } \\
\text { ahhhhh yung communication na parang may barriers talaga ..." }\end{array}$ & Interest and Devices Used \\
\hline
\end{tabular}


Lived experience of literature teachers and students in the new normal

Continued ...

Teacher Howell Internal External is the interest and your heart in teaching ... even the technology ...

Teacher Doty $\quad \ldots$ internet connection and when the teacher is not technologically acquainted ...

Teacher Jasmine $\quad$... the internal factors is that my knowledge when it comes to technology ... my ability and knowledge to technology is just like basic.

Teacher Rosh The Internal factor is knowledge in technology ... External factors are so many like the internet connection, the gadget, the support from the others its very very important.

Teacher Mark For the internal factors ... the ability of yeah the decision-making to incorporate technology in teaching especially in literature ... And for the external factors naman ahhh ... Internet connection..

With a theme, Various Intrinsic and Extrinsic Factors in Teaching, the teacher-participants revealed that Motivation and Environment, Interest and Devices Used, and Internet Connection and Technical Knowledge were the reasons that mattered to them in achieving the quality of teaching literature online.

Brooks and Grajek (2020) stated that this rapid transition of all teaching consequently provides a unique opportunity to observe the extent to which teachers actually felt prepared for OTL. It is important to acknowledge that teachers' perceptions of their readiness for OTL represent a multifaceted problem. Particularly in relation to the rapid transition to full online teaching, this shift constituted major changes in teaching practice.

\section{Thematic Chart H.2}

Barriers in Learning Literature Online

\begin{tabular}{|c|c|c|}
\hline Participant & Responses & Subordinate Themes \\
\hline Student Sean & $\begin{array}{l}\text { Sa panloob po ay yung stress... At ang panlabas naman po ay } \\
\text { yung maingay kapaligiran ... }\end{array}$ & $\begin{array}{l}\text { Emotional Distress and } \\
\text { Unstable Internet Connection }\end{array}$ \\
\hline Student Marga & $\begin{array}{l}\text { Sa panloob ay stress at mga emosyonal na pangagailangan } \\
\text { po. .... ang panlabas ... ingay sa paligid, responsibilidad sa loob } \\
\text { ng tahanan, at mga pangagailangan para sa pag-aaral. }\end{array}$ & \\
\hline Student Redge & $\begin{array}{l}\text { Sa panlabas po ay ingay ng kapaligiran at mahinang signal at sa } \\
\text { panloob naman po ay ang pag iisip ng mga negative thoughts } \\
\text { about po sa mga nangyayari ... }\end{array}$ & \\
\hline Student Joydel & $\begin{array}{l}\ldots \text { will and motivation po. ... Sa panlabas naman ... problem } \\
\text { po sa wifi sa connection ... }\end{array}$ & \\
\hline Student Charrise & $\begin{array}{l}\text { Sa panloob po ay kakayahan ng mental at emosyonal ... Sa } \\
\text { panlabas na kadahilanan naman po ng internet connection ... }\end{array}$ & \\
\hline Student Ruzzle & $\begin{array}{l}\text {... intelektuwal, emosyonal, pisikal, at mental para sa panloob } \\
\text { na kadahilanan. Sa panlabas na kadahilanan naman po ay ang } \\
\text { mga kalagayan po pang teknolohiya ... }\end{array}$ & \\
\hline Student Althea & $\begin{array}{l}\text {... motivation po na matuto, gawin ang mga aktibidad ng tama } \\
\text { sa oras at makinig po sa aralin. Sa panlabas naman po ay hindi } \\
\text { maayos na paligid o lugar po ng pag-aaral ... }\end{array}$ & \\
\hline Student Nelson & $\begin{array}{l}\text { Yung determinasyon kop o na makapag-aral ... Kung sa } \\
\text { panlabas naman po ay ang kakayahan ko pong pang pinansyal } \\
\text { para makapag-aral gamit ang online ... }\end{array}$ & $\begin{array}{l}\text { Being determined and Financial } \\
\text { Stability }\end{array}$ \\
\hline $\begin{array}{l}\text { Student Danielle } \\
\text { Student Jaymark }\end{array}$ & $\begin{array}{l}\text { Ingay ng kapaligiran at mabagal na internet koneksyon. } \\
\ldots \text { nawawalan po ng interes o gana at sa panlabas naman po ay } \\
\text { dahil sa mahinang signal ng internet. ... mga taong maiingay at } \\
\text { hindi makaunawa na may nag-aaral. }\end{array}$ & Environmental Distractions \\
\hline
\end{tabular}

With a theme, Barriers in Learning Literature Online, the student-participants shared that Emotional Distress and Unstable Internet Connection, being determined, and Financial Stability and Environmental Distractions were the reasons that greatly affected the quality of learning they received in learning literature online.

Cannell (2017) stated that the lack of internet access was a recurring theme. The impact of poverty on digital participation also emerged as a theme, which subsequently impacts attitudes about the internet in terms of 
motivation to learn online and desire to access materials. Lack of home ownership of computers is a barrier to online learning. The systemic issue is reflected in the differential graduation rates between computer owners and non-owners and the resulting varying ability to participate in online learning. Part of the reason this differential is so high is that computer ownership correlates with a number of other factors associated with youth's educational achievement, such as family income, race, or parents' education and internet access.

\subsection{How do you assess the quality of online education you gave (teachers) or you receive (students) in dealing} with literature?

\section{Thematic Chart I.1}

Varied Teaching Performance Status

\begin{tabular}{|c|c|c|}
\hline Participant & Responses & Subordinate Themes \\
\hline Teacher Ron & Well I could say that there is a satisfaction from both parties ... & Fair \\
\hline Teacher Kenneth & $\begin{array}{l}\text { Actually na evaluate naman ako fairly justly and okay } \\
\text { naman ... }\end{array}$ & \\
\hline Teacher Renzo & $\begin{array}{l}\text { Teaching literature online for me is less effective than face to } \\
\text { face classes... }\end{array}$ & Less Effective \\
\hline Teacher Howell & $\begin{array}{l}\text { To be honest it's inaccurate in a sense na hindi lahat ng bata is } \\
\text { mage-gets ang sinabi mo ... }\end{array}$ & Inaccurate \\
\hline Teacher Rosh & $\begin{array}{l}\ldots \text { for me it's inaccurate pa as of this moment since we are just } \\
\text { in first year of this modality. }\end{array}$ & \\
\hline Teacher Doty & ... questionable pa eh because we know it matters to teaching. & Uncertain \\
\hline Teacher Jasmine & $\ldots$ its unreliable $\ldots$. & Unreliable \\
\hline Teacher Mischelle & $\begin{array}{l}\text { Ahmmm online classes kasi in my case ha it is more on } \\
\text { spoon-feeding ... }\end{array}$ & Spoon-feeding \\
\hline
\end{tabular}

With a theme, Varied Teaching Performance Status, the teacher-participants said that the quality of teaching online was Less Effective, Inaccurate, Uncertain, Unreliable, and Spoon-feeding. On the other hand, only two literature teacher-participants shared that the assessment result on them was Fair.

In connection, Coman, Tiru, Schmitz, Stanciu, and Bulara, (2020) stated that teachers did not have the necessary technical skills, and they did not manage in such a short time to adapt their teaching style or to appropriately interact with students in the online environment in order to assure high standards of the teaching process. The technical skills of teachers could be represented by their ability to use different functions offered by the E-learning platform to adapt their teaching style to the online environment, for example, using the video conference function where students can actively participate because teachers could make them moderators. These technical skills also refer to the ability to present topics through screen sharing, to use synchronous chat during presentations, to offer students the possibility to work in teams during seminars, to post various links on the platform concerning various sources of information, to make short videos for specific laboratories/seminars and to post them on the platform.

\section{Thematic Chart I.2}

Varied Learning Assessments

\begin{tabular}{|c|c|c|}
\hline Participant & Responses & Subordinate Themes \\
\hline Student Sean & $\ldots$ hindi po sapat ... & Not enough \\
\hline Student Danielle & ... ito ganun ka epektibo ... & \\
\hline Student Marga & $\ldots$ hindi poi to sapat $\ldots$ & \\
\hline Student Jaymark & Hindi po sapat ang oras na inilalaan sap ag-aaral na ito ... & \\
\hline Student Charrise & $\begin{array}{l}\text {... hindi po talaga masasabing mataas o mababa ang nakukuha } \\
\text { mo .... }\end{array}$ & \\
\hline Student Joydel & ngunit hindi poi to sapat ... & \\
\hline Student Ruzzle & Hindi po masasabi na ito ay makatotohanan ... & Unrelialistic \\
\hline Student Nelson & $\begin{array}{l}\text {... hindi ko po masusuri ang kalidad neto hanggat wala po } \\
\text { akong nakikitang pag babago.. }\end{array}$ & Cannot Assess Yet \\
\hline Student Redge & $\begin{array}{l}\text {.. maganda ito kumpara sa iba. Ang mga guro at mga } \\
\text { estudyante ay responsible naman po. }\end{array}$ & Effective \\
\hline
\end{tabular}


Lived experience of literature teachers and students in the new normal

Continued

Student Althea Maayos po ang aralin na ibinabahagi sa amin at may nalalaman

din naman po kami ...

With a theme, Varied Learning Assessments, the student-participants said that the quality of learning online was Not enough, Unrelialistic, and Cannot Assess Yet. On the other hand, only two student-participants said that it was Effective because they believed that their teachers provided lessons in the best way.

In relation, Munoz and Mackay (2019) stated that assessment could be considered the most challenging part of the transition to distance learning for an institution used to the face-to-face oral or written exam, as the control shift towards the students makes it hardly possible to ensure that students are not cheating.

4.10What do you suggest to make the teaching and learning of literature through online education more effective and delightful?

\section{Thematic Chart J.1}

Improving Literature in Online Teaching Process

\begin{tabular}{|c|c|c|}
\hline Participant & Responses & Subordinate Themes \\
\hline Teacher Ron & $\begin{array}{l}\text { Well I think DEPEd should create a specific platform for } \\
\text { teaching ... create something like software or a platform for } \\
\text { teaching }\end{array}$ & $\begin{array}{l}\text { Creating New Platforms and } \\
\text { Applications }\end{array}$ \\
\hline Teacher Renzo & $\begin{array}{l}\text {...the teachers should incorporate reading downloadable } \\
\text { stories. poem, novels, etc. from the internet ... }\end{array}$ & \\
\hline Teacher Doty & $\begin{array}{l}\ldots \text { the school could have an access in a certain application like } \\
\text { ah e-book... }\end{array}$ & \\
\hline Teacher Howell & $\begin{array}{l}\ldots \text { They can use other applications aside from what we are } \\
\text { currently using... }\end{array}$ & \\
\hline Teacher Joy & Provide more interactive activities ... & Providing Interactive Activities \\
\hline Teacher Kenneth & $\begin{array}{l}\ldots \text { they have to give them workshop and seminars using } \\
\text { technology especially on the delivery of the instruction proper }\end{array}$ & Providing ICT Training \\
\hline Teach Rosh & $\begin{array}{l}\text { Give us teachers a hands on training on technological aspects } \\
\text { because }\end{array}$ & \\
\hline Teacher Jasmine & $\begin{array}{l}\ldots \text { teachers must be open minded eh to learn new things even } \\
\text { you are in a service na for a long year. }\end{array}$ & Being Open-minded \\
\hline Teacher Mark & $\begin{array}{l}\text { I suggest we can involve the family member in terms of } \\
\text { collaboration they can still develop their skills. }\end{array}$ & Involving family members \\
\hline Teacher Mischelle & $\begin{array}{l}\ldots \text { chunk the lesson and get the most important details. } \\
\text { Secondly, ... provide some videos to students ... Lastly, ... } \\
\text { focus on active learning not spoon feeding ...." }\end{array}$ & Encouraging active learning \\
\hline
\end{tabular}

With a theme, Improving Literature in Online Teaching Process, the teacher-participants divulged that Creating New Platforms and Applications, Providing Interactive Activities, Providing ICT Training, Being Open-minded, involving family members, and Encouraging active learning could help the teaching more effective and delightful.

According to Chatterjee and Chakraborty (2020), online education has been on the fringe for a long time. The COVID-19 pandemic made it the mainstream. They found that the students considered online education a viable alternative under the current circumstances. They however think that there is scope for improvement. Instructors should try to make online education better acceptable among students. Techniques like flipped classroom, case studies, and gamification may be introduced in online education and their effects may be studied.

\section{Thematic Chart J.2}

Effective Online Learning Recommendations

\begin{tabular}{lll}
\hline \multicolumn{1}{c}{ Participant } & \multicolumn{1}{c}{ Responses } & Subordinate Themes \\
\hline $\begin{array}{l}\text { Student Jaymark } \\
\text { Student Sean }\end{array}$ & $\begin{array}{l}\text {... mas maaga pang pagbibigay ng mga handouts o module ... } \\
\text { mag-aaral at ang guro ... }\end{array}$ & Time Management \\
\hline
\end{tabular}


Pordunzalan, R.

\begin{tabular}{|c|c|c|}
\hline Student Danielle & $\begin{array}{l}\text { Mas bigyan pa po ng oras o panahon ang mga estudyante sa } \\
\text { mga pinapagawang aktibidad ... }\end{array}$ & \\
\hline Student Redge & $\begin{array}{l}\text {... Kailangan na may magandang iskedyul po sa subject na } \\
\text { ito ..... }\end{array}$ & \\
\hline Student Marga & $\begin{array}{l}\text {... siguraduhin dapat po ang kahandaan ng mga guro lalo na sa } \\
\text { teknikal na aspeto ... }\end{array}$ & $\begin{array}{l}\text { Ensuring Teachers' Technical } \\
\text { Readiness }\end{array}$ \\
\hline Student Ruzzle & $\begin{array}{l}\text { Bigyang konsiderasyon po ang bawat estudyante na hindi } \\
\text { lubusang nakakasabay sa online learning ... }\end{array}$ & Giving Considerations \\
\hline Student Nelson & $\begin{array}{l}\text { Bigyan po nila nang pansin ang mga estudyante na hindi po } \\
\text { makasabay araw-araw sa pag online class ... }\end{array}$ & \\
\hline Student Althea & $\ldots$ mas gawing interaktib ang pag-aaral. ... & $\begin{array}{l}\text { Establishing } \\
\text { Learning }\end{array}$ \\
\hline Student Joydel & $\begin{array}{l}\text { Magtala po ng mga gawain na makaka enganyo sa nga mag } \\
\text { aaral at mas gawin pong interaktib po ang pagtuturo. }\end{array}$ & \\
\hline Student Charrise & $\begin{array}{l}\text {... dapat laging naka open camera o irequire po ang mga } \\
\text { estudyante... }\end{array}$ & Imposing Open Webcam Policy \\
\hline
\end{tabular}

With a theme, Effective Online Learning Recommendations, the student-participants divulged that Time Management, Ensuring Teachers' Technical Readiness, Giving Considerations, Establishing Interactive Learning, and Imposing Open Webcam Policy. In all modes of distance teaching, the ability to cultivate the relationship with distant learners is essential. More and more students are choosing to improve skills using online learning. Many say that it is beneficial, whereas others argue that online education has disadvantages as well. Students are in search of many new ways of learning literature online. Unfortunately, this manner brings not only advantages but also disadvantages. The online process of education is advantageous for many reasons. An individual can use a computer access and Internet connection anywhere.

On the other hand, online learning has negative aspects. There is a limited social interaction that prevents studying how much time an individual want. Furthermore, online learning is the only method of communication of online learning through e-mail, chat rooms, or discussion groups. Teachers and students cannot interact with others face to face. It is an unnatural communication way. Somehow students do not see and feel the relationship with classmates and feedbacks. Despite that, education must go on and continually improve so students will engage more in the lesson.

In connection, it is not always easy to do online learning for both students and teachers but still they could find a lot of benefits. Britanny (2015) stated that online learning offers an excellent way for students to broaden their educational opportunities and stay competitive in the ever-demanding realm of education. Students need to be self-motivated, independent, and responsible learners. Understanding one's learning style and skills will allow students to more accurately determine if online learning is suitable for them. Overall, online learning environments allow for learning to occur in a setting that is not restricted by place or time. Online learning has the ability to disassemble barriers that have been constructed by poverty, location, disability, as well as other factors. Also, Stern (2020) explained that there were a lot of benefits that they could get from online learning such as convenience, enhanced learning, leveling of the playing field, increasing interaction, innovative teaching, improved administration, maximize physical resources and outreach.

The literature teachers and students find difficulties online, such as confusion, because there is much information on the internet. On the other hand, teachers have limited ideas on the activities and unfamiliar with some applications that can be incorporated online. As a result, the researcher developed a "compilation of online literature" with suggested links to avoid confusion in the learning materials and guide them in the teaching and learning process. Also, suggested activities and applications were provided to produce more fun and delightful learning of literature.

\section{Conclusions/reflection and directions for future use}

On the phenomenological study on the lived experiences of the Literature teachers and students, thirteen (13) themes emerged. Under the first theme, Diverse Perspectives, most participants answered that distance learning 
modality was an Alternative Modality because they believed that they could still teach and learn without physical interaction between them.

For the second theme, Different Viewpoints, participants divulged the different ideas on the distance learning modality before they used it in teaching and learning literature online. They explained that the sudden transitions were one of the significant changes and biggest challenges in education.

Under the third theme, Various Preparations, the participants elaborated on the various preparations they had to do in teaching and learning literature online. Participants researched and studied the lesson because there was plenty of information on the internet and selected the most appropriate one.

For the fourth theme, Varied Adjustments, the participants revealed that different ways were adopted in teaching and learning literature online. The teachers used different kinds of technology-based materials in teaching to create an effective learning material that they used in facilitating online classes.

Under the fifth theme, Distinct Challenges, the participants elaborated distinct challenges that affected and impacted online education. The lack of technical knowledge caused the teacher-participants to question and doubt themselves as they were aware of not being capable of some aspects when technologies were concerned.

For the sixth theme, Various Solutions to Cope with Difficulties, the participants shared various solutions that helped them coped with the difficulties encountered. The majority of the participants divulged that resourcefulness was one of the best ways to get through in the teaching and learning process.

Under the seventh theme, Teaching and Learning Environment Conditions, the teacher-participants elucidated the teaching and learning conditions. The majority of them shared those environmental distractions greatly affected their focus on various tasks.

For the eighth theme, Various Intrinsic and Extrinsic Factors in Teaching, teacher-participants shared that motivation, interest, and technical knowledge were the intrinsic factors that challenged them in the teaching and learning literature online.

Under the ninth theme, Barriers in Learning Literature Online, the majority of the student-participants stated that the emotional distress and unstable internet connection were the internal and external barriers that hindered them from learning literature online. Determination to learn and financial stability was considered a factor in clear and smooth online learning. Lastly, environmental distractions had an impact on providing and receiving lectures.

For the tenth theme, Varied Teaching Performance Status, the teacher-participants revealed that the performances were less effective, inaccurate, uncertain, unreliable, and spoon-fed education. Only two mentioned that they delivered fairly.

Under the eleventh theme, Varied Learning Assessments, most student-participants unveiled that the quality of learning they received was not enough. Some students explained that it was also unrealistic and could not assess yet.

For the twelfth theme, Improving Literature in Online Teaching Process, the teacher-participants recommended different means that helped them improve literature online. It called for the creation of new platforms and applications that could be more easy but still engaging. They suggested that mandatory ICT training was needed for the enhancement of skills. Also, they had to provide interactive activities and encourage an active learning environment to make it fun and more delightful. Also, some suggested being open-minded about the circumstances they dealt on the teaching process. The involvement of family was necessary since the teaching and learning online happened at home.

Under the thirteenth theme, Effective Online Learning Recommendations, the student-participants shared 
meaningful recommendations to achieve effective online learning. Time management was considered in different ways as it talked about the self- preparations, completion of tasks, and the learning facets. Also, students shared that the teachers should be technologically ready and acquainted. Giving considerations were also important because of the different learning environments of the students. Students like interactive learning and strictly have an open webcam policy. These recommendations could help them learn better with fun on their faces and delightfulness in their selves.

The researcher believes that this study will contribute to educational research, future researchers, and future educators.

Based on the conclusions/reflections drawn, the following RECOMMENDATIONS are:

1. Literature teachers are strongly encouraged to continuously possess determination in dealing with the current learning modality in the Philippines education and to cope with the emerging modern technology-based methods by maximizing the uses of technical and technological applications in the creation process of teaching and learning materials that will allow students to engage more in literature. Therefore, literature Teachers may attend specialized training and various seminars about modern technology such as tools and applications that will help them deliver smooth teaching of literature online. Also, keen planning of lessons and careful designing of learning materials that boost lively and active learning and an exciting online environment that cater to the different needs of heterogeneous students is highly needed.

2. Twenty-first-century learners are advised to be more focused and active in online discussions that will be helpful for them in terms of learning and growing their love for literature. They are encouraged to be open and communicate with their teachers privately to clear doubts, either through virtual learning platforms or calls. They are highly encouraged to read literary pieces and some English books to foster appreciation in literature and help them broaden their knowledge not only of the subject but also their consciousness of the world and widen their vocabulary. Students are also advised to inform their parents and friends about the schedules of online learning so that there will be no distractions from their side. Restrict the study area for others to come during live sessions and video calls. They may relax in the breaks set on the timetable. In this way, students will concentrate on learning and lessen stress along the learning process.

3. Curriculum developers are recommended to integrate technology and other modern methods into the learning package for schools. It will allow teachers and students to maximize their time and enhance the teaching-learning process in an online environment.

4. School administrators may introduce and provide seminars to teachers in teaching online. Also, training that will provide those different strategies and materials to teach literature effectively among their students. In addition, school administrators must require qualifications or assessments on teachers to know their capability and knowledge in technology before requiring them to teach online.

5. The Department of Education is highly encouraged to strengthen and continuously support the schools, teachers, students, and parents by providing free holistic webinars and training to develop and improve distance learning modality in the Philippines. Especially in learning Literature online, they may integrate different activities like public online speaking, interactive role-play conversation, performing poems, and making video reflections online to boost student's confidence and give students opportunities to apply the lessons they have gained and developed.

6. Parents may cultivate a robust family support system. They may be reminded that they perform a significant role in the motivation of their children. They may often check their children about the struggles and achievements they have in their daily classes.

7. Future researchers, with this research, may use the findings of this paper to develop another study that will be beneficial and substantial to address existing and upcoming problems in teaching literature online among

92 Consortia Academia Publishing (A partner of Network of Professional Researchers and Educators) 
Lived experience of literature teachers and students in the new normal

students that will provide long-term solutions on how teachers can teach effectively in their online class.

\section{References}

Abu, E. (2020). Learning must continue in the new normal. Retrieved from https://www.manilatimes.net/2020/10/22/campus-press/learning-must-continue-in-the-new-normal/783 $\underline{769 /}$

Akamai. (2017). Akamai's State of the Internet. Retrieved from https://www.akamai.com/us/en/multimedia/documents/state-of-the-internet/q1-2017-state-of-the-interne t-connectivityreport.pdf

Almotahida Education Group. (2020). Started with letters in the 19th century. History of “distance learning”. Retrieved from https://www.almotahidaeducation.com/

Arinto, P. (2016). Issues and challenges in open and distance e-learning: Perspectives from the Philippines. Retrieved from http://www.irrodl.org/index.php/irrodl/article/view/1913/3651

Balansag, S. (2018). Improvement of the teaching style: From traditional teacher-centered to student-centered teaching style. Academic Paper.

Besser, A., Flett, G. L., \& Zeigler-Hill, V. (2020). Adaptability to a sudden transition to online learning during the COVID-19 pandemic: Understanding the challenges for students. Scholarship of Teaching and Learning in Psychology. Advance online publication. https://doi.org/10.1037/st10000198

Brown, C. (2017). Advantages and disadvantages of distance learning. Retrieved from https://www.eztalks.com/elearning/advantages-and-disadvantages-of-distance-learning.html

Brown, C. (2017). Benefits of distance learning. Retrieved from https://www.eztalks.com/elearning/benefits-ofdistance-learning.html

Ceniza, M. L (2020). How does "new normal" looks in the Philippine Education System? Retrieved from https://www.newsbeastph.com/2020/07/how-does-new-normal-looks-in-philippine.html

Chakraboty, P., Mittal, P., Gupta, M., Yadav, S., \& Arora, A. (2020). Opinion of students on online education during the COVID-19 pandemic. Human Behavior and Emerging Technologies, 3(3), 357-365. https://doi.org/10.1002/hbe2.240

Cherry, K. (2019). History and key concepts of behavioral psychology. Very well mind. Retrieved from https://www.verywellmind.com/behavioral-psychology

Chertov, V. F., \& Antipova, A. M. (2016). Russian literature lesson in the modern information and educational space. Retrieved from https://www.shsconferences.org/articles/shsconf/pdf/2016/07/shsconf_eeia2016_01016.pdf

Choo, S. (2020). Nurturing global citizens through literature education. Retrieved from https://singteach.nie.edu.sg/issue72-research1/

Coman, C., Tiru, L., Schmitz, L., Stanciu, C., \& Bulara, M. (2020). Online teaching and learning in higher education during the coronavirus pandemic: Students' perspective. Sustainability, 12(24), 10367. https://doi.org/10.3390/su122410367

Dhawan, S. (2020). Online learning: A panacea in the time of COVID-19 crisis. Retrieved from https://journals.sagepub.com/doi/full/10.1177/0047239520934018

Elhashash, M. (28 February, 2019). Distance learning (Its concept, history, main principles, and techniques).

Retrieved from

https://blog.praxilabs.com/2019/02/28/distance-learning-its-concept-history-main-principles-and-techni ques/

Felter, C., \& Maizland, L. (2020). How countries are reopening schools during the pandemic. Council of Foreign Relations. Retrieved from https://www.cfr.org/backgrounder/how-countries-are-reopening-schools-duringpandemic

Garcia, M. (2017). E-learning technology adoption in the Philippines: An investigation of factors affecting Filipino college students' acceptance of learning management systems. Retrieved from https://www.researchgate.net/publication/323576195_E-Learning_Technology_Adoption_in_the_Philip 
Pordunzalan, R.

pines_An_Investigation_of_Factors_Affecting_Filipino_College_Students'_Acceptance_of_Learning Management_Systems

Grimus, M. (2020). Emerging technologies: Impacting learning, pedagogy and curriculum development. UNESCO.

Guta, M. (2020). Distance learning demand offers opportunity for small education businesses. Retrieved from https://smallbiztrends.com/2020/03/distance-learning-technology.html

Hutt, M. (2017). Top 10 disadvantages of distance learning. Retrieved from https://www.eztalks.com/elearning/top-10- disadvantages-of-distance-learning.html

Industrytap.com. (2020). Emerging technologies in distance learning. Retrieved from https://www.industrytap.com/emerging-technologies-in-distance-learning/52940

Janssen, S. M., Fialho, T. O., \& Rijlaarsdam, G. (2016). The impact of literature education on students' perceptions of self and others: Exploring personal and social earning experiences in relation to teacher approach. https://doi.org/10.17239/L1ESLL-2016.16.04.01

Joaquin, J., Biana, H., \& Dacela, M. (2020). The Philippine higher education sector in the time of COVID-19. Frontiers in Education. https://doi.org/10.3389/feduc.2020.576371

Jong, P. (2020). Impact of moving to online learning on the way educators teach. Medical Science Educator, 30 , 1003-1004. https://doi.org/10.1007/s40670-020-01027-7

Kamani, V. (2019). Emerging technologies: Reimagining how students learn with e-learning. Retrieved from https://elearningindustry.com/emerging-technologies-reimagining-students-learn

Karthik, V. (2020). The importance of online learning in the times of COVID-19 and beyond. Retrieved from https://www.highereducationdigest.com/the-importance-of-online-learning-in-the-times-of-covid-19-an d-beyond/

Kolb, L. (2017). Learning first, technology second. The educator's guide to designing authentic lessons. International Society for Technology in Education.

Kulal, A., \& Nayak, A. (2020). A study on perception of teachers and students toward online classes in Dakshina Kannada and Udupi District. Asian Association of Open Universities Journal, 15(3), 285-296. https://doi.org/10.1108/AAOUJ-07-2020-0047

Lagua, B. (2020). Teaching in the new normal. Retrieved from https://www.manilatimes.net/2020/10/30/business/columnists-business/teaching-in-the-new-normal/788 $\underline{7621}$

Llego, M. (2021). DepEd learning delivery modalities for school year 2020-2021. https://www.teacherph.com/deped-learning-delivery-modalities/

Lynch, M. (2017). Digital literacy is the most important lifelong learning tool. Retrieved from https://www.thetechedvocate.org/digital-literacy-important-lifelong-learning-tool/

Magulod, G. C. (2018, December 22). Innovative learning tasks in enhancing the literary appreciation skills of students. https://doi.org/10.1177/2158244018820382

McLeod, S. A. (2018). Jean Piaget's theory of cognitive development. Piaget's 4 stages of cognitive development: Background and key concepts of Piaget's theory. Simply Psychology. https://www.simplypsychology.org/piaget.html

Moneymax. (2020). What is distance learning and how does it work? Retrieved from https://www.moneymax.ph/lifestyle/articles/distance-learning-philippines

Papadopoulou, A. (2020). What is distance learning? Definitions, examples \& more. Retrieved from https://www.learnworlds.com/distance-learning/

Rapanta, C., Botturi, L., Goodyear, P., Guardia, L., \& Koole, M. (2020). Online university teaching during and after the Covid-19 crisis: Refocusing teacher presence and learning activity. Postdigital Science and Education, 2, 923-945. https://doi.org/10.1007/s42438-020-00155-y

Rosemary. (2015). The history of distance learning. Retrieved from https://www.unicaf.org/the-history-of-distance-learning/

Sadeghi. (2019). A shift from classroom to distance learning: Advantages and limitations. Retrieved from http://ijreeonline.com/article-1-132-en.pdf

94 Consortia Academia Publishing (A partner of Network of Professional Researchers and Educators) 
Lived experience of literature teachers and students in the new normal

Santos, A. P. (2020). In the Philippines, distance learning reveals the digital divide. Retrieved from https://eu.boell.org/en/2020/10/06/philippines-distance-learning-reveals-digital-divide

Singson, E. (2020). The open distance learning of the Philippines and the copyright laws. Retrieved from https://erickasingsonwordpresscom.wordpress.com/2015/12/14/reconciling-the-free-sharing-of-resource s-under-ra-10650-and-the-authors-right-under-the-copyright-laws/

Tarek, S. (2016). Distance learning: The role of the teacher. Retrieved from http://www.docuri.com

Tiamson, J. (2020). Distance education is a gift. Retrieved from https://manilastandard.net/mobile/article/325105

Tibon, J. (2020). The new normal in basic education. Retrieved from https://www.lexology.com/library/detail.aspx?g=f4c146a9-7ef0-4bc1-8d6d-e6516a4a14ff

Tria, J. Z. (2020). The COVID-19 pandemic through the lens of education in the Philippines: The new normal. https://www.ijpdll.com/download/the-covid-19-pandemic-through-the-lens-of-education-in-the-philippi nes-the-new-normal-8311.pdf

Tuscano, J. (2020). It's not about online learning: A reflection on the "new normal" in education (Part 1). Retrieved from https://francisjimtuscano.com/2020/04/27/its-not-about-online-learning-a-reflection-on-the-new-normal -in-education-part-1/

Winthrop, R. (2020, April 10). Top 10 risks and opportunities for education in the face of COVID-19. Brookings. Retrieved from

https://www.brookings.edu/blog/education-plus-development/2020/04/10/top-10-risks-and-opportunitie s-for-education-inthe-face-of-covid-19/ 
Pordunzalan, R.

96 Consortia Academia Publishing (A partner of Network of Professional Researchers and Educators) 